\title{
FREE SPACES: IDENTITY, EXPERIENCE AND DEMOCRACY IN CLASSICAL ATHENS*
}

Most modern works on Greek history accept a categorical distinction between different identities and statuses in classical Athens: there was a deep chasm between the male citizens' club and those excluded: foreigners, slaves and women; and the identity of male citizen, slave, foreigner and woman was clear, well defined, easy to establish, immutable and unchallenged. ${ }^{1}$ Admittedly, this is not simply a modern construction: there are innumerable references in the ancient texts, which present this view of identity and make it a legitimate perspective for modern scholars to adopt. ${ }^{2}$

These images created by ancient sources became acceptable to scholars belonging to very different traditions and schools. For those scholars who believe that politics can be best understood through a study of institutions, what matters primarily is the distinction between those who have the right to participate in these institutions and those who do not. ${ }^{3}$ Accordingly, it was easy to accept the existence of a clear distinction between the citizens and everybody else. For those who accept a structuralist perspective, the polarities between citizen and metic, free and slave, Greek and barbarian, or men and women offered a fruitful way to apply their approach to Greek history. ${ }^{4}$ For those who accept status and order as essential categories of analysis, the distinction between different status groups becomes essential in an analysis of Greek society. ${ }^{5}$ Finally, for those who work within a tradition of legal history, the clear legal distinctions are the essential means of interpretation. ${ }^{6}$

It is the aim of this article to challenge these long-entrenched assumptions. I want to argue that the distinction between citizens, metics and slaves was often difficult to establish in Athens; that this was connected to the functions of Athenian democracy; that citizens, metics and slaves formed mixed and interacting cultures in collaboration and conflict; and that these interactions were created and enabled by what I will call free spaces. This discussion will raise a second important issue: the interpretation of Athenian democracy. I will argue that many of the current approaches to Athenian democracy have a strong elitist perspective and that we have to turn our attention to a bottom-down perspective; the concept of free spaces can play an important role in changing perspective.

* The essence of this article was originally presented in a Nottingham-Leicester conference on 'Space and identity in the ancient world' in April 2006. I would like to thank the participants, the anonymous reader for $C Q$, Matt Edge and Steve Hodkinson for their suggestions. All translations come from the relevant volumes of the Loeb Classical Library.

1 See e.g. P. Cartledge, The Greeks: A Portrait of Self and Others ${ }^{2}$ (Oxford, 2002); S. Pomeroy, Goddesses, Whores, Wives and Slaves (New York, 1975), 78.

2 See e.g. Dem. 22.55, 59.122; Arist. Pol. 1326a18-22.

3 See e.g. M. H. Hansen, 'On the importance of institutions in an analysis of Athenian democracy', $C \& M 40$ (1989), 108-13.

4 P. Vidal-Naquet, Le chasseur noir: Formes de pensée et formes de société dans le monde grec (Paris, 1983).

5 M. I. Finley, The Ancient Economy² (Berkeley-Los Angeles, 1985), 35-61; D. Whitehead, The Ideology of the Athenian Metic (Cambridge, 1977), v.

${ }^{6}$ S. C. Todd, The Shape of Athenian Law (Oxford, 1993), 167-200. 
Finally, my interpretation necessitates taking a position on an old but still lively debate among ancient historians: the character and function of ancient economies and societies. There has been an interpretative current that puts agriculture and the peasant-citizen at the centre of the emergence and function of Athenian democracy. ${ }^{7}$ There is no question that this is a very important aspect, and that it is necessary for every explanation of the character of Athenian democracy. But I will argue that we have undervalued the importance of the non-agricultural population in classical Athens; ${ }^{8}$ and that the artisans, wage-labourers, sailors and petty shopkeepers played an essential role in the creation of the particular character of Athenian democracy and the blurring of identities.

\section{THE BLURRING OF IDENTITIES}

There is an alternative view, which is often forgotten, brushed aside or explained away by modern scholars, but clearly manifested in ancient sources, that the establishment and definition of identity and status in classical Athens was problematic and a real issue. Many sources show that it was difficult and often impossible to establish an individual's identity and status; that individual or collective claims to a certain identity and status were often forcefully challenged; and that the issue of identity in classical Athens was an issue of debate, anxiety and disagreement.

A couple of examples will suffice to show that this was the case. In Lysias 23 the defendant, Pancleon, claims that he was an enfranchised Plataean and therefore a legitimate Athenian citizen; ${ }^{9}$ his opponent initially believed that he was a metic, but in the process of finding out whether he was truly a citizen, he claims to have witnessed an episode in which two different people claimed Pancleon as their own slave; different people viewed Pancleon as a citizen, a metic, a slave. ${ }^{10}$ Many sources assert that it was often difficult, if not impossible, to recognize who was citizen, metic or slave in Athens. According to a famous passage from the Old Oligarch,

Now among the slaves and metics at Athens there is the greatest uncontrolled wantonness; you can't hit them there, and a slave will not stand aside for you. I shall point out why this is their native practice: if it were customary for a slave (or metic or freedman) to be struck by one who is free, you would often hit an Athenian citizen by mistake on the assumption that he was a slave. For the people there are no better dressed than the slaves and metics, nor are they any more handsome. ${ }^{11}$

\footnotetext{
${ }^{7}$ See e.g. E. M. Wood, Peasant-citizen and Slave: The Foundations of Athenian Democracy (London, 1988); V. D. Hanson, The Other Greeks: The Family Farm and the Agrarian Roots of Western Civilization (New York and London, 1995).

8 A recent welcome corrective in E. M. Harris, 'Workshop, marketplace and household: the nature of technical specialisation in classical Athens and its influence on economy and society', in P. Cartledge, E. E. Cohen and L. Foxhall (edd.), Money, Labour and Land: Approaches to the Economies of Ancient Greece (London, 2001), 67-99.

${ }^{9}$ On the enfranchisement of Plataeans, see K. Kapparis, 'The Athenian decree for the naturalisation of the Plataeans', GRBS 36 (1995), 359-78.

${ }^{10}$ Modern scholars usually simply try to play the role of the judge, instead of being interested in the phenomenon itself; see N. F. Jones, The Associations of Classical Athens. The Response to Democracy (New York-Oxford, 1999), 83-6; Todd (n. 6), 167-9.

${ }^{11}$ Constitution of the Athenians 1.10. See S. Cataldi, 'Akolasia e isegoria di meteci e schiavi nell'Atene dello Pseudo-Senofonte: una riflessione socio-economica', in M. Sordi (ed.), L'opposizione nel mondo antico (Milan, 2000), 75-101.
} 
In two speeches of Demosthenes a similar problem is encountered; and it is important to note that in these two cases it is not a matter of polemic, as one could argue (and all too often it has been argued) in the case of the anti-democrat Old Oligarch.

And not only did they go off with my furniture, men of the jury, but they were even on the point of taking away my son, as though he were a slave, until Hermogenes, one of my neighbours, met them and told them that he was my son. ${ }^{12}$

More than this, as they were neighbours and my farm adjoined theirs, they sent into it in the daytime a young boy who was an Athenian, and put him up to plucking off the flowers from my rose-bed, in order that, if I caught him and in a fit of anger put him in bonds or struck him, assuming him to be a slave, they might bring against me an indictment for assault. ${ }^{13}$

In both cases it is impossible to tell a slave boy from the son of an Athenian citizen, and this is simply taken as a matter of fact by the speaker. Pittalacus, a person described as a public slave, has created a nightmare for generations of scholars: in the events narrated by Aeschines is he still a public slave or is he already a freedman? Or is he indeed a private slave, as Hegesandrus claims? ${ }^{14}$ It seems impossible to tell. This is equally true when we come down to women: the case of Neaera, a onetime slave prostitute, who managed to pass for decades as an Athenian woman and the wife of an Athenian citizen, is a famous one; ${ }^{15}$ there is no reason to believe that it was unique, given the examples above. ${ }^{16}$

Finally, it is notorious, but usually simply dismissed as false, that Athenian politicians were routinely charged, both in serious and non-serious contexts, with foreign and/or servile origin. Some of the most important Athenian politicians like Demosthenes, Aeschines, Hyperbolus, not to mention Cleon or Cleophon, were charged with foreign or servile origins. ${ }^{17}$ This was not empty rhetoric: Euxitheus, who had served as $\delta \eta_{\mu} \mu \rho \chi o s$ and $\phi \rho \alpha \tau \rho \iota \alpha \rho \chi o s$, lost his citizenship in a $\delta \iota \alpha \psi \eta \dot{\phi} \phi \iota \iota s$ conducted by his deme, aimed to excise from the deme registers members who had illegally assumed Athenian citizenship. ${ }^{18}$ It is probable that Euxitheus was not simply accused of not being an Athenian citizen, but of being a slave or a child of slaves; his father had a foreign accent, according to Euxitheus, due to his staying in Leucas as a slave after being captured $(\$ 18)$; his mother was involved in a variety of occupations mostly associated with slaves, being a nurse among others $(\$ 30,35)$; therefore, it is probable that his opponents claimed that his parents were really slaves or freedmen, and he himself a slave or freedman. ${ }^{19}$

12 Against Evergus and Mnesibulus 61.

13 Against Nicostratus 16.

${ }^{14}$ Aeschines, Against Timarchus 54-64.

15 Demosthenes, Against Neaira.

${ }^{16}$ An interesting parallel emerges from the lead curse tablets from ancient Athens: in one of them the writer curses the woman Pataicion, 'whom Epainetus claims to be his daughter and pledged ( $\eta \gamma \gamma u ́ \eta \sigma \epsilon \nu)$ as a wife to Echesthenes of Troezen'; the status of Epainetus is unclear from the text, but he is probably a metic; R. Wünsch, Defixionum tabellae, Appendix to IG III (Berlin, 1897), no. 55, 5-7.

${ }_{17}$ V. Ehrenberg, The People of Aristophanes: A Sociology of Old Attic Comedy (Oxford, 1943), 119-20; J. Ober, Mass and Elite in Democratic Athens: Rhetoric, Ideology and the Power of the People (Princeton, 1989), 270-9; E. E. Cohen, The Athenian Nation (Princeton, 2000), 112.

${ }_{18}$ Demosthenes, Against Eubulides.

${ }^{19}$ Failure to appreciate that Euxitheus is not simply trying to prove that he is a citizen, but also that his parents were not slaves or freedmen, has led to serious misinterpretations of Athenian attitudes to manual and wage labour. 


\section{SPACE AND IDENTITY}

This different view of status and identity in classical Athens is now espoused by a number of scholars; ${ }^{20}$ Edward Cohen in particular has in his recent book offered a devastating attack on the old orthodoxy. ${ }^{21}$ But how is one to explain these blurred identity lines? Space plays an important role in explaining the ambivalence of Athenian identity. ${ }^{22}$ One dimension, which has recently been explored by Cohen and others, is the nature of the space of the Athenian polis. Athens was an atypical polis, because it was too large: the Athenian polis comprised the whole of Attica, thus encompassing a whole region; in other cases, as for example in Boeotia, the region was divided into a number of poleis, which could potentially join together to form a koinon or constitute an ethnos. ${ }^{23}$ Athens was not a face-to-face society, a $\pi$ ó$_{\imath}$ s $\epsilon \dot{v} \sigma \dot{v} \nu 0 \pi \tau o s$ in the Aristotelian sense, ${ }^{24}$ Athens was an imagined community, a polity in which most members did not know each other. ${ }^{25}$ The blurring of identities can therefore be attributed to the large number of citizens and of the overall population, the dispersal of demes over a whole region, and the constraints created by topography and communications. Thucydides and Isocrates expressed well the issue at hand:

An exaggerated belief in the numbers of the conspirators also demoralised the people, rendered helpless by the magnitude of the city, and by their want of intelligence with each other, and being without means of finding out what those numbers really were. ${ }^{26}$

For Athens is so large and the multitude of people living here is so great, that the city does not present to the mind an image easily grasped or sharply defined, but, like a turbid flood, whatever it catches up in its course, whether men or things, in each case it sweeps them along pell-mell, and in some cases it imbues them with a reputation which is the opposite of the true. ${ }^{27}$

Related to this is an Athenian peculiarity in the division of space. At the time of the reforms of Cleisthenes and the reorganization of the tribes in the late sixth century, each citizen was registered in the deme where he was resident. But Athenian citizens would in the future inherit and retain the deme identification of their ancestors at the time of the reforms of Cleisthenes, irrespective of their actual residence. ${ }^{28}$ Therefore, changes in residence, and in particular the internal migration to Athens and Piraeus

20 E. E. Cohen, Athenian Economy and Society: A Banking Perspective (Princeton, 1992); V. Hunter, Policing Athens. Social Control in the Attic Lawsuits, 420-320 B.C. (Princeton, 1994); Jones (n. 10); M. Adak, Metöken als Wohltäter Athens: Untersuchungen zum sozialen Austausch zwischen ortsansässigen Fremden und der Burgergemeinde in klassischer und hellenistischer Zeit, ca. 500-150 v. Chr. (Munich, 2003); B. Bäbler, Fleißige Thrakerinnen und wehrhafte Skythen: Nichtgriechen im klassischen Athen und ihre archäologische Hinterlassenschaft (Stuttgart, 1998).

${ }^{21}$ Cohen (n. 17).

22 See C. Schnurr-Redford, Frauen im klassischen Athen: sozialer Raum und reale Bewegungsfreiheit (Berlin, 1996).

${ }^{23}$ See Xen. Mem. 5.3.2-4 for an illuminating comparison between Athenians and Boeotians.

24 Pol. 1327a1-3.

25 For the concept of the imagined community, see B. Anderson, Imagined Communities. Reflections on the Origin and Spread of Nationalism (London-New York, 1991); see also Cohen (n. 17); G. Anderson, The Athenian Experiment: Building an Imagined Political Community in Ancient Attica, 508-490 B.C. (Ann Arbor, 2003).

26 Thuc. 8.66.3-4.

27 Isoc. Antid. 172.

28 D. Whitehead, The Demes of Attica, 508/7-ca. 250 B.C.: A Political and Social Study (Princeton, 1986), 67-77. 
from the rural demes, and the pattern of scattered landholdings would mean that deme membership and deme life could diverge widely. ${ }^{29}$ Already in the second half of the fifth-century the rural deme of Icarion had enough resident non-demesmen to legislate that tragic choregoi should be drawn in pairs from both demesmen and residents. ${ }^{30}$ On the other hand, metics were enrolled in their deme of residence ${ }^{31}$ and many slaves, the so-called $\chi \omega \rho$ is oikov $\nu \tau \epsilon s$, were living apart from their masters, very often in a different deme. ${ }^{32} \mathrm{~A}$ demesman of Halimus could have lived for two generations in Athens, while the deme of Halimus could be inhabited by citizens registered in a different deme, metics and slaves living apart from their masters. The significance of rural farmsteads, as opposed to nucleated settlements, in certain demes would further enhance the problems of establishing and defining identity in the local demes. ${ }^{33}$ This aspect has been sufficiently emphasized by Cohen. ${ }^{34}$

A second aspect of space is equally important, but far less well studied. The Athenian polis did not constitute a secluded and autonomous space: Athens was the centre of a large network moving goods, people and ideas, which involved the Aegean, the Black Sea, the eastern Mediterranean and Sicily. ${ }^{35}$ Athens depended on traders and sailors to import the huge amounts of cereals that were necessary for its economic survival ${ }^{36}$ on foreign, metic and slave rowers for its navy $;{ }^{37}$ and on thousands of labourers, artisans, builders and intellectuals for a variety of functions. ${ }^{38}$ Isocrates has put it nicely:

Moreover, she (Athens) has established her polity in general in such a spirit of welcome to strangers and friendliness to all men, that it adapts itself both to those who lack means, and to those who wish to enjoy the means, which they possess, and that it fails to be of service neither to those who are prosperous, nor to those who are unfortunate in their own cities; nay, both classes find with us what they desire, the former the most delightful pastimes, the latter the securest refuge. Again, since the different populations did not in any case possess a country that was self-sufficing, each lacking in some things and producing others in excess of their needs, and since they were greatly at a loss, where they would dispose of their surplus, and whence they would import what they lacked, in these difficulties also our polis came to the rescue; for she

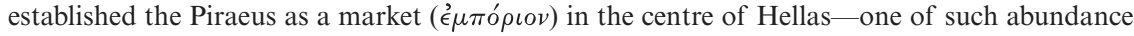

${ }^{29}$ Cohen (n. 17), 113-20; Jones (n. 10), 123-50.

${ }^{30} I G \mathrm{I}^{3}, 254$; Whitehead (n. 28), 76-7.

${ }^{31}$ Already around 460 the city deme of Scambonidae provided for the participation of metics in its sacrifices: $I G \mathrm{I}^{3}, 244$.

32 E. Perotti, 'Esclaves choris oikountes', in Actes du Colloque 1972 sur l'esclavage (Paris, 1974), 47-56; R. Osborne, 'The potential mobility of human populations', OJA 10 (1991), 231-52.

33 See H. Lohmann, 'Agricultural and country life in Classical Attica', in B. Wells (ed.), Agriculture in Ancient Greece (Stockholm, 1992), 29-60; Y. Suto, 'Isolated farms in classical Attica', Kodai 4 (1993), 1-13.

${ }^{34}$ Cohen (n. 17), 104-29.

${ }^{35}$ A. Tchernia and D. Viviers, 'Athènes, Rome et leurs avant-ports: "mégapoles" antiques et trafics méditerranéens', in C. Nicolet (ed.), Mégapoles méditerranéennes: géographie urbaine rétrospective (Rome, 2000), 761-801.

${ }^{36} \mathrm{~J}$. Vélissaropoulos, Les nauclères grecs: recherches sur les institutions maritimes en Grèce et dans l'Orient hellénisé (Geneva-Paris, 1980); C. M. Reed, Maritime Traders in the Ancient Greek World (Cambridge, 2003).

${ }^{37}$ P. Hunt, Slaves, Warfare, and Ideology in the Greek Historians (Cambridge, 1998), 83-101; H. van Wees, 'Politics and the battlefield: ideology in Greek warfare', in A. Powell (ed.), The Greek World (London, 1995), 157-62.

38 See P. McKechnie, Outsiders in the Greek Cities in the Fourth Century B.C. (London-New York, 1989), 142-77. 
that the articles, which it is difficult to get, one here, one there, from the rest of the world, all these it is easy to procure from Athens. ${ }^{39}$

Therefore, Athens was a cosmopolitan centre; and as such there was a need of laxity and toleration in order to be able to maintain social peace and the continuation of the networks of manpower and goods, on which Athens depended. This has been well-captured by the Old Oligarch:

If anyone is also startled by the fact that they let the slaves live luxuriously there and some of them sumptuously, it would be clear that even this they do for a reason. For where there is a naval power, it is necessary from financial considerations to be slaves to the slaves in order to take a portion of their earnings, and it is then necessary to let them go free. And where there are rich slaves, it is no longer profitable in such a place for my slave to fear you...For this reason we have set up equality of speech ( $i \sigma \eta \gamma o \rho^{\prime} \alpha$ ) between slaves and free men, and between metics and citizens. The city needs metics in view of the many different trades and the fleet. Accordingly, then, we have reasonably set up a similar equality also for the metics. ${ }^{40}$

But, as the Old Oligarch further comments, it is not simply a matter of laxity; the position of Athens as a cosmopolitan centre has also profound effects on Athenian customs and life:

If there should be mention also of slighter matters, first, by virtue of their naval power, the Athenians have mingled with various peoples and discovered types of luxury. Whatever the delicacy in Sicily, Italy, Cyprus, Egypt, Lydia, Pontus, the Peloponnese, or anywhere else - all these have been brought together into one place by virtue of naval power. Further, hearing every kind of dialect, they have taken something from each; the Greeks rather tend to use their own dialect, way of life, and type of dress, but the Athenians use a mixture from all the Greeks and non-Greeks. ${ }^{41}$

We shall have the opportunity in the rest of this article to observe how this mixture of dialect, way of life and type of dress took place. It would be highly illuminating to study Athens in the light of other cosmopolitan centres, like Venice or Amsterdam, famous for their toleration; ${ }^{42}$ or to compare Athens with other Mediterranean commercial centres, like Ottoman Smyrna or Marseilles. ${ }^{43}$ In the beginning of the Republic, Socrates goes down to Piraeus to celebrate the introduction of the Thracian cult of Bendis and is clearly impressed by the procession of the Thracians. ${ }^{44}$ The introduction of foreign cults and their role in shaping changing identities was the result of Athens' place within a wider space.

I now wish to consider a third dimension of space in classical Athens, which I will call, borrowing the expression from a fine book by Sara Evans and Harry Boyte, ${ }^{45}$ free spaces. Free spaces are spaces that brought together citizens, metics, slaves and women, created common experiences and interactions, and shaped new forms of identity. We can define a number of such spaces: the agora, the workplace, the tavern, the house, the trireme, and the cemetery. Let us have a closer look at the agora.

${ }^{39}$ Isoc. Paneg. 41-3.

40 Constitution of the Athenians 1.11-12.

${ }^{41}$ Constitution of the Athenians 2.7-8.

${ }^{42}$ P. Burke, Venice and Amsterdam: A Study of Seventeenth-century Elites (London, 1974); see e.g. F. Braudel, Civilization and Capitalism, vol. 3: The Perspective of the World (London, 1984), $184-8$.

${ }^{43}$ On Ottoman Smyrna, see E. Frangakis-Syrett, The Commerce of Smyrna in the Eighteenth Century, 1700-1820 (Athens, 1992). See also the articles in Nicolet (n. 35).

${ }^{44}$ Plato, Republic 327A; see R. Parker, Athenian Religion: A History (Oxford, 1996), 170-5.

${ }^{45}$ S. M. Evans and H. C. Boyte, Free Spaces: The Sources of Democratic Change in America (New York, 1986). 


\section{THE AGORA}

The study of Athenian democracy has been divided between two approaches: one institutional, focusing on analysis of Athenian public institutions and the way they functioned; ${ }^{46}$ the other emphasizing the role of discourses and the political ideas that informed the function of Athenian democracy. ${ }^{47}$ Finally, there is a large amount of work on the social and economic history of ancient Athens, ${ }^{48}$ but in most cases these works largely refrain from dealing with Athenian democracy and its politics. ${ }^{49}$

The standard view presents the assembly and the lawcourts as the essential settings of Athenian politics. Given that it was mainly elite speakers who dominated the assembly, and elite litigants who dominated the corpus of court speeches that have survived, modern scholars have largely given a highly elitist tinge to their images of Athenian democracy. Even Moses Finley, a great opponent of elitism in other respects, could put things like this:

A fifth-century Athenian Thersites could not have been beaten by a nobleman for his presumption; he would have been shouted down by his equals. ${ }^{50}$

For most people, democracy mainly resides in their ability to choose between different versions and options offered by the elite, all political changes, decisions and innovations being initiated by elite politicians for sinister, personal or idealistic reasons; and in the mysterious ability of the demos to define the terms of debate and discourse that the elite will use. ${ }^{51}$

A different perspective will emerge once we turn our attention to free spaces. Athenian democracy was not conducted simply within institutional settings. There are very many indications that political life and discussion took place in a variety of other contexts; ${ }^{52}$ what is essential for my arguments is the different terms on which discussion took place outside the institutional setting; and, even more, the fact that non-institutional settings were not restricted to the citizens, but were open to everybody.

The focus of this article is the space of the agora. The Greeks had a number of different forms of agoras. ${ }^{53}$ According to Aristotle,

46 See e.g. P. J. Rhodes, The Athenian Boule (Oxford, 1972); M. H. Hansen, The Athenian Democracy in the Age of Demosthenes: Structure, Principles, and Ideology (Oxford, 1991).

47 C. Meier, Entstehung des Begriffs Demokratie: vier Prolegomena zu einer historischen Theorie (Frankfurt am Main, 1970); N. Loraux, The Invention of Athens: The Funeral Oration in the Classical City (Cambridge, MA, 1986); Ober (n. 17); D. Musti, Demokratía: origini di un'idea (Rome, 1995).

48 Hunter (n. 20); Cohen (n. 17), (n. 20).

49 Among the few exceptions, see W. R. Connor, 'Civil society, Dionysiac festival, and the Athenian democracy', in J. Ober and C. W. Hedrick (edd.), Demokratia: A Conversation on Democracies, Ancient and Modern (Princeton, 1996), 217-26; B. S. Strauss, 'The Athenian trireme, school of democracy', in Ober and Hedrick (n. 49), 313-26.

50 'The freedom of the citizen in the Greek world', in Economy and Society in Ancient Greece (London, 1981), 83.

${ }^{51}$ See Ober (n. 17), 336-9.

52 A rare example raising the issue is S. Lewis, News and Society in the Greek Polis (London, 1996), 14-15.

53 R. Martin, Recherches sur l'agora grecque: études d'histoire et d'architecture urbaine (Paris, 1951); U. Kenzler, Studien zur Entwicklung und Struktur der griechischen Agora in archaischer und klassischer Zeit (Bern-Frankfurt am Main, 1999). 
It is convenient that below this site should be laid out an agora of the kind customary in Thessaly, which they call a free agora, that is, one which has to be kept clear of all merchandise and into which no artisan or farmer or any other such person may intrude unless summoned by the magistrates. ${ }^{54}$

Conservative thinkers were very hostile towards the mixture of politics, work and commerce in the agora, as Aristotle testifies. ${ }^{55}$ The Athenian agora was very different: it included public buildings, workshops, shops and booths: it brought together public life, social life, work and exchange. ${ }^{56}$ As Eubulus put it,

Everything together in the same place will be there for sale at Athens, figs, summoners, bunches of grapes, turnips, pears, apples, witnesses, roses, medlars, sausages, honeycombs, chickpeas, lawsuits, beestings, beestings-pudding, myrtle berries, allotment machines, irises, lambs, water clocks, laws, indictments. ${ }^{57}$

The agora played a very important role in Athenian social life; as Lysias says:

For each of you is in the habit of paying a call at either a perfumer's or a barber's or a shoemaker's shop, or wherever he may chance to go - in most cases, it is to the tradesmen who have set up nearest the agora, and in fewest, to those who are farthest from it. So if any of you should brand with roguery the men who visit my shop, clearly you must do the same to those who pass their time in the shops of others; and if to them, to all the Athenians: for you are all in the habit of paying a call and passing your time at some shop or other. ${ }^{58}$

Let us have a look at two passages that indicate the importance of political discussion in the agora:

And my accuser has dared to tell you that it was I who drove Critobulus, Cersobleptes' ambassador, from the ceremony - in the presence of the allies, under the eyes of the generals, after the people had voted as they did! Where did I get all that power? How could the thing have been hushed up? If I had really dared to undertake such a thing, would you have suffered it, Demosthenes? Would you not have filled the agora with your shouts and screams, if you had seen me, as you just now said you did, thrusting the ambassador away from the ceremony? 59

Charidemus set out to visit the Persian King, wishing to do you some practical service apart from mere talking, and anxious at his own peril to win safety for you and every Greek. Demosthenes went round the agora making speeches and associating himself with the project. 60

According to Dinarchus and Aeschines, his enemies, an essential part of Demosthenes' political campaign in favour, or against, a certain measure would be political discussion in the agora. ${ }^{61} \mathrm{He}$ would make speeches, shout, and discuss with other people, in order to present his agenda. There are many other passages, which make even more precise what speaking in the agora entailed. Isocrates 18 is a private

54 Pol. 1331a30-5.

55 See e.g. Ar. Clouds 985-92, 1002-8.

56 R. E. Wycherley, 'The market of Athens', G\&R 2 (1956), 2-23; P. Millett, 'Encounters in the Agora', in P. Cartledge, P. C. Millett and S. von Reden (edd.), Kosmos: Essays in Order, Conflict and Community in Classical Athens (Cambridge, 1998), 203-28; S. von Reden, Exchange in Ancient Greece (London, 1995), 106-11; F. Börner, Die bauliche Entwicklung Athens als Handelsplatz in archaischer und klassischer Zeit (Munich, 1996).

57 KA fr. 74

58 Lysias, On the Pension 20; see also Demosthenes, Against Aristogeiton 52; S. Lewis, 'Barber's shops and perfume shops: "symposia without wine", in Powell (n. 37), 423-41.

59 Aeschines, On the Embassy 86.

${ }^{60}$ Dinarchus, Against Demosthenes 32.

${ }^{61}$ A practice shared by his political opponents: see Demosthenes, Against Meidias 104. 
speech, but it concerns the case of Callimachus, who claimed to have been maltreated by his opponent during the Thirty, in a case that had clear political overtones:

Although so many persons had been present, when the events took place, Callimachus here, as if no one had any knowledge of the matter, himself mixed with the crowds ( $o^{\prime} \chi \lambda \circ$ ) , sat in the workshops ( $\left.\dot{\epsilon}^{\prime} \rho \gamma \alpha \sigma \tau \eta^{\prime} \rho \iota \alpha\right)$, and related again and again his story, how he had suffered outrageous treatment at my hands and had been deprived of his money. ${ }^{62}$

The same story of mixing with crowds, sitting in workshops and making speeches is repeated in a number of other passages.

If you show us that he has ever been to Macedon or entertained any of the people in his own home, that he knows a Macedonian intimately or meets any of them; if you prove that he has said one word about such matters, either in a shop ('́) $\left.\rho \gamma \alpha \sigma \tau \eta^{\prime} \rho \iota \nu\right)$ or in the agora or anywhere else, instead of quietly and modestly minding his own business as much as any other citizen, the jury may do what they like with him. ${ }^{63}$

And when the power recently shifted from them to Philip they then chose to flatter him, and Democrates of Aphidna who never leaves their sides . . makes jokes on the city's misfortunes, abusing you in the agora by day and then coming at evening to dine at your table. ${ }^{64}$

And yet we are quite indifferent to the fact that our polity has been corrupted, nor do we even

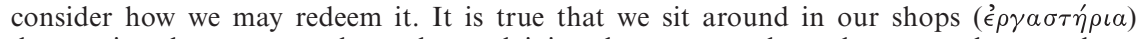
denouncing the present order and complaining that never under a democracy have we been worse governed. ${ }^{65}$

What is interesting in all these passages is that for the average Athenian citizen, who would rarely if ever have the chance to address the assembly and present his ideas there, and was only a listener at the important political trials in the courts, the proof of his political views and identity comes through the positions he has argued for, defended, or attacked in the agora.

According to Plutarch, Alcibiades followed a similar procedure to convince the Athenians of the necessity and desirability of the Sicilian expedition; and the passage clearly shows the importance of discussions in the agora for the formation of public policy in the assembly:

Before the assembly had met at all, Alcibiades had already corrupted the multitude and got them into his power by means of his sanguine promises, so that the youth in their training-schools

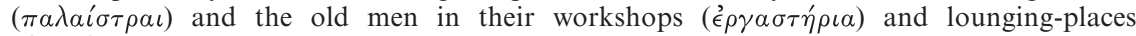
$(\dot{\eta} \mu \iota \kappa \dot{v} \kappa \iota \iota \alpha)$ would sit in cluster drawing maps of Sicily, charts of the sea about it, and plans of the harbours and districts of the island which look towards Libya. ${ }^{66}$

I hope there is no need to cite further passages in order to prove the importance of crowd-gathering, speeches, and discussions in the workshops, shops, and the open spaces of the agora. But before moving on, it is vital to stress two points: it is clear that Athenian politicians had to mix with poor labourers, artisans, shopkeepers, hucksters and peasants on a constant day-to-day basis, in order to pursue their political agendas. The conditions of such encounters are well illustrated in a story about Pericles related by Plutarch:

62 Isocrates, Against Callimachus 9.

63 Hypereides, In Defence of Euxenippus 21.

${ }^{64}$ Hypereides, Against Philippides 2.

65 Isocrates, Areopagiticus 15.

${ }^{66}$ Life of Nicias 12.1; see also Life of Alcibiades 17.3. 
It is, at any rate, a fact that, once on a time when he had been abused and insulted all day long by a certain lewd fellow of the baser sort, he endured it all quietly, though it was in the agora, where he had urgent business to transact, and towards evening went away homewards unruffled, the fellow following along and heaping all manner of contumely upon him. When he was about to go in doors, it being now dark, he ordered a servant to take a torch and escort the fellow in safety back to his own home. ${ }^{67}$

Is it not possible that this day-to-day encounter and discussion between Athenian politicians and poor subaltern Athenians might explain much more about Athenian politics than the orthodox model? In the orthodox model, the silent demos sits, listens, and chooses between the various proposals brought forward by the elite in the assembly and court; but in this non-institutional setting, one can imagine poor, common Athenians speaking their own minds, presenting their grievances, even suggesting courses of action that might be subsequently taken up by the assembly. Why should the introduction of pay for the jury or the $\theta \epsilon \omega \rho \iota \kappa \alpha$ be attributed solely to elite Athenian politicians and not to this kind of encounter? Theophrastus gives a good illustration of what these subaltern speakers would look and sound like (from

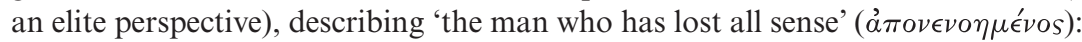

He would seem to be one of those who call on crowds (óx $\left.\chi^{\circ} \iota \iota\right)$ to gather around, then rail at them and hold forth in a loud cracked voice. Meanwhile, some come along to hear, and others go away before they can hear him; so that some get the beginning, others a syllable, others a section of his message. He is only satisfied when showing off his loss of sense to a public meeting ( $\left.\pi \alpha \nu \eta^{\prime} \gamma v \rho \iota s\right) \ldots$ They are tiresome, these foul-tongued loud-mouthed people, who make the agora and the workshops ('́) $\left.\rho \gamma \alpha \sigma \tau \eta^{\prime} \rho \iota \alpha\right)$ echo with their noise. ${ }^{6} 8$

But let me move to the crucial point: the political space of the agora was not restricted to Athenian citizens: it was also open to women, metics, slaves, and foreigners. They were all present in the agora, working, crafting, selling and buying, talking. ${ }^{69}$ It is difficult to see how a political discussion that took place in the agora, involving poor citizen artisans, shopkeepers, labourers, would exclude all those other people present: metics, slaves, women. ${ }^{70}$ They were there, working, discussing and selling their goods right next to the citizens: how could they fail to listen and even to participate? Indeed, there are many references that show that this was exactly the case. Plutarch gives a nice illustration when discussing how the Athenians heard of the catastrophe in Sicily:

The Athenians, they say, put no faith in the first tidings of the calamity, most of all because of the messenger who brought them. A certain stranger, as it would seem, landed at the Piraeus, took a seat in a barber's shop, and began to discourse of what had happened, as if the Athenians already knew all about it. The barber, on hearing this, before others learned of it, ran at the top of his speed to the upper city, accosted the archons, and at once set the story going in the agora. Consternation and confusion reigned, naturally, and the archons convened an assembly and brought the man before it. But, on being asked from whom he had learned the matter, he was unable to give any clear answer, and so it was decided that he was a rumour-monger

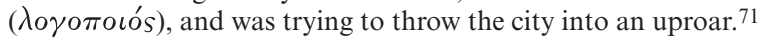

${ }^{67}$ Life of Pericles 5.2-3.

${ }^{68}$ Theophrastus, Characters 6.7-10.

${ }^{69}$ On women's labour, see R. Brock, 'The labour of women in classical Athens', CQ 44 (1994), 336-46; on metics see Whitehead (n. 5); Bäbler (n. 20); Adak (n. 20); on slaves see Cohen (n. 17), $130-54$.

${ }^{70}$ A short comment in this respect in A. Burford, Craftsmen in Greek and Roman Society (London, 1972), 156. 
It is a reasonable assumption that the barber involved was not an Athenian citizen: otherwise he would not have been tortured. ${ }^{72}$ As we see in this passage, a foreigner visits Athens and starts a political discussion (it is clear from the passage that the purpose of the foreigner's discussion is not simply to convey information, since he assumes the Athenians already knew about the catastrophe; rather he discusses the implications or the reasons for the catastrophe); a non-citizen barber informs the archons and starts a discussion in the agora. Theophrastus gives another example of an Athenian discussing with people of low status in his portrait of the rumour-

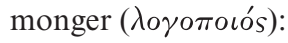

He has a man just back from the actual battle - a soldier, or a slave of the piper Asteios, or the contractor Lycon-from whom he claims to have heard how Polyperchon and the King have won a military victory and Cassander has been taken prisoner. And if anyone says to him 'Do you believe this?', he says he does, because it is the talk of the city, discussion is intensifying, all are of one voice. And, he says, there was a great bloodbath, and the faces of those in office (oi $\dot{\epsilon} v$ $\tau o \hat{\imath}$ s $\pi \rho a ́ \gamma \mu \alpha \sigma \iota v)$ support his story - he has seen for himself how changed they all are. ${ }^{73}$

In the Ecclesiazusae, Aristophanes gives an example of how non-citizens could profit from the free space of the agora:

First woman How beautiful this is, my dearest Praxagora, how clever! But where, pray, did you learn all these pretty things?

Praxagora When the countryfolk were seeking refuge in the city, I lived on the Pnyx with my husband, and there I learnt to speak through listening to the orators. ${ }^{74}$

The example here refers to the assembly and the abnormal circumstances of the mass movement to Athens during the Peloponnesian War; given that women are practising here in order to speak disguised in the Assembly, it is natural that their experience should be seen to derive from overhearing the proceedings of the assembly; in real life, I would suggest that it would be the experience of hearing the political discussions taking place in the agora that would influence women and have an effect on them. ${ }^{75}$ There are many references in comedy to women working in the agora, asserting their rights and position. This does not imply a rosy picture: the depressing image provided by the following passage of Aristophanes must have been the experience of many a woman working in the agora:

Lysistrata But what's sillier than to go on an errand of buying a fish Carrying along an immense Gorgon-buckler instead of the usual platter or dish?

Woman B A phylarch I lately saw, mounted on horse-back, dressed for the part with long ringlets and all,

Stow in his helmet the omelette bought steaming from an old woman who kept a food-stall.

71 Plutarch, Life of Nicias 30.

72 D. S. Allen, The World of Prometheus: The Politics of Punishing in Democratic Athens (Princeton, 2000), 100.

73 Theophrastus, Characters 8.4-8.

74 241-4. Note also that Demosthenes, while still a little child, and thus not allowed to enter the assembly place, begs his slave attendant $(\pi \alpha \iota \delta \alpha \gamma \omega \gamma$ ós) to let him listen to Callistratus of Aphidna while addressing the assembly, and thus falls in love with oratory; Plutarch, Life of Demosthenes 844B.

75 See e.g. Lysistrata 507-21, 1124-7. 
Nearby a soldier, a Thracian, was shaking wildly his spear like Tereus in the play, To frighten a fig-girl while unseen the ruffian filched from her fruit-trays the ripest away. ${ }^{76}$

Clearly working women could be and were exploited and abused in classical Athens. But it is equally important to pay attention to those passages that imply that Athenian women were confident enough and in a position to strike back: one comes from a scene in the Wasps:

Baker's Wife (to Chaerephon) Come to my help, I beg you, in the name of the gods! This cursed man, when striking out right and left with his torch, knocked over ten loaves worth an obolus apiece, and then, to cap the deal, four others.

Bdelycleon Do you see what lawsuits you are drawing upon yourself with your drunkenness? You will have to plead.

Philocleon $\quad$ Oh, no, no! A little pretty talk and pleasant tales will soon settle the matter and reconcile her with me.

Baker's Wife Not so, by the goddesses twain! It shall not be said that you have with impunity spoilt the wares of Myrtia, the daughter of Ancylion and Sostrates.

Philocleon Listen, woman, I wish to tell you a lovely anecdote.

Baker's Wife By Zeus, no anecdotes for me, thanks.

Philocleon One night Aesop was going out to supper. A drunken bitch had the impudence to bark near him. Aesop said to her, 'Oh, bitch, bitch! You would do well to sell your wicked tongue and buy some wheat'.

Baker's Wife You make a mock of me! Very well! I don't care who you are, I shall summon

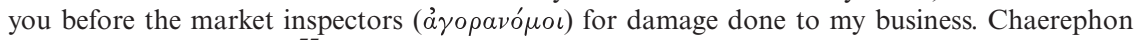
here shall be my witness! ${ }^{77}$

Women asserting proudly their free identity are found in other passages of Aristophanes:

Men Did you hear that insolence?

Women I'm a free woman, I.

Men I'll make you hold your tongue.

Women $\quad$ You are not on a jury now, you know! ${ }^{78}$

Magistrate Indeed, you slut! Where is the archer now?Arrest this woman, tie her hands behind

Lysistrata If he brushes me with a finger, by Artemis, the public slave, he'll be sorry for it. 79

The crescendo comes when the army of Athenian women, who exercise a variety of professions in the agora, manage to defeat the Scythian archers based on their free identity:

76 Lysistrata $561-4$.

77 1396-1408.

78 Lysistrata 378-80.

79 Lysistrata 433-6. 
Lysistrata By the Goddesses, you'll find that here await you

Four companies of most pugnacious women

Armed cap-a-pie from the topmost louring curl

To the lowest angry dimple.

Magistrate On, Scythians, bind them.

Lysistrata On, gallant allies of our high design,

Vendors of grain-eggs-pulse-and-vegetables,

Ye garlic-tavern-keepers of bakeries,

Strike, batter, knock, hit, slap, and scratch our foes,

Be finely imprudent, say what you think of them ...

Enough! retire and do not rob the dead.

Magistrate How basely did my archer-force come off.

Lysistrata Ah, ha, you thought it was a herd of slaves

You had to tackle, and you didn't guess

The thirst for glory ardent in our blood. ${ }^{80}$

One result of this free space of the agora, bringing together poor citizens, metics, slaves and women is the deep politicisation of Athenian culture. ${ }^{81}$ This feature is superbly ridiculed by Aristophanes:

Bdelycleon Everything is now tyranny with us, no matter what is concerned, whether it be large or small. Tyranny! I have not heard the word mentioned once in fifty years, and now it is more common than salt-fish, the word is even current on the agora. If you are buying gurnards and don't want anchovies, the huckster next door, who is selling the latter, at once exclaims, 'That is a man whose kitchen savours of tyranny!' If you ask for onions to season your fish, the green-stuff woman winks one eye and asks, 'Ha, you ask for onions! are you seeking to tyrannize, or do you think that Athens must pay you your seasonings as a tribute?'

Xanthias Yesterday I went to see a whore about noon and told her to get on top; she flew into a rage, pretending I wanted to restore the tyranny of Hippias.

Bdelycleon That's the talk that pleases the people. ${ }^{82}$

I think that Aristophanes' comic depictions create a consistent picture. Being present and even participating in the political setting of the free space of the agora had a profound effect on how people were thinking and behaving: the women claiming that they are free and should be respected, the working women that assert themselves against assault, the green-stuff woman using political language to abuse her customer, all point in the same direction: the free space of the agora extended politics even to those excluded. Aristophanes ridicules again this politicization in another passage from the Frogs; Euripides is reprimanded for the social effects of his dramatic art:

Euripides Then from the opening words I permitted nothing idle; my woman spoke, as did the slave as well, or master, maiden, or old woman.

Aeschylus Then really shouldn't you be put to death for daring this?

${ }^{80}$ Lysistrata 452-64.

${ }^{81}$ On women and democracy, see M. H. Jameson, 'Women and democracy in fourth-century Athens', in E. W. Robinson (ed.), Ancient Greek Democracy: Readings and Sources (Oxford, 2004), 281-92.

82 Aristophanes, Wasps 488-503. For the understanding of this passage, see J. Davidson, Courtesans and Fishcakes: The Consuming Passions of Classical Athens (London, 1997), 278-308. 
Euripides No, by Apollo, for this was a democratic thing I did. 83

There is satire in Euripides' claim that giving speech to slaves and women was a democratic thing; but the very expression of this idea is remarkable and tallies in with all the other evidence we have adduced. ${ }^{84}$

Political discussion outside the assembly was not restricted to the agora. A tantalizing glimpse is given by Theophrastus in his portrait of the 'country bumpkin'

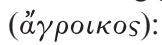

He distrusts friends and family, preferring to discuss important business with his slaves, and he reports the proceedings of the assembly to the hired labourers $(\mu \iota \sigma \theta \omega \tau \circ i)$ working on his farm. ${ }^{85}$

I assume that the hired labourers are free, since they are distinguished from the slaves, and metics, because, if they were citizens, discussing the news of the assembly with them would not be so condemnable. One wonders how they would respond to the news of the assembly; how their foreign political background and experience would shape their understanding and reaction to the events; and what kind of discussion would ensue.

Is there any evidence that non-citizens took advantage of the blurring of identities to participate directly in Athenian institutions and practices? There is not much, and the reason is understandable: nobody who resorted to such practices would be foolish enough to advertise it. But how plausible would such a thing be? A fascinating example concerns Athenogenes, an Egyptian metic, involved in selling perfumes in late fourth-century Athens. ${ }^{86}$ The cunning Athenogenes arranges in collaboration with Antigone, a prostitute, to sell to a wealthy young Athenian citizen two male slaves along with their perfume workshop, which is heavily in debt. The details of the story are not of direct concern here, but what happens later on is quite revealing $(\S 29-31)$ :

During the war against Philip, he left the city just before the battle and did not serve with you at Chaeronea. Instead, he moved to Troezen, disregarding the law, which says that a man who moves in wartime shall be indicted and summarily arrested if he returns... He is so degraded and so true to type wherever he is, that even after his arrival at Troezen, when they had made him a citizen, he became the tool of Mnesias the Argive and, after being made a magistrate by him, expelled the citizens from the city.

An Egyptian perfume seller has the obligation to fight for Athens, along with thousands other foreigners living in Athens; instead he escapes, goes to a tiny obscure place like Troezen, is enrolled as a citizen, even becomes a magistrate. ${ }^{87}$ How common was such an event? If we judge from the tone of the passage, it does not seem very extraordinary; the moral outrage is against his disenfranchising citizens, not in his becoming one. If such a thing was possible in a small place like Troezen, then what should we infer about Athens? Is this not the way to explain the mass participation of metics and slaves in the movement to overthrow the Thirty and restore democracy? ${ }^{88}$

83 Frogs 948-52.

${ }^{84}$ See the commentary of K. Dover, Aristophanes: Frogs (Oxford, 1993), ad. loc.

85 Theophrastus, Characters 4.3-4.

86 Hypereides, Against Athenogenes.

87 See D. Whitehead, Hypereides: The Forensic Speeches (Oxford, 2000), 287-8, 339-41.

88 See D. F. Middleton, 'Thrasybulus' Thracian support', CQ 32 (1982), 298-303; G. Bakewell, 'Lysias 12 and Lysias 31: metics and Athenian citizenship in the aftermath of the Thirty', GRBS 40 (1999), 5-22. 
Beyond the above hypotheses, there are certainly a number of attestations, which deserve to be presented. Two come from Demosthenes' Against Meidias. The first one raises the problem of the confusion created by the significant number of Athenians who had lost their political rights at some point in their lives:

Pyrrhus, men of Athens, one of the Eteobutadae, who was indicted for serving on a jury when he was in debt to the Treasury, was thought by some of you to deserve capital punishment, and he was convicted in your court and put to death. And yet it was from poverty, not from insolence, that he tried to get the juryman's fee. ${ }^{89}$

The second presents a case of direct participation of non-Athenians in the decisions of the assembly; this is how Meidias tries to explain his condemnation:

Again, I expect that he will not shrink from vilifying the people and the Assembly, but will repeat what he had the effrontery to say when the plaint was first brought in: that the meeting was composed of men who had stayed at home when they ought to have gone to the front and who had left their posts unguarded, and that he was condemned by the votes of chorus-men and aliens and the like. 90

The last example comes from Plutarch's description of the trial and execution of Phocion:

Clitus secured them till they had convoked an assembly of the people, which was open to all comers, neither foreigners, nor slaves, nor those who had been punished with disfranchisement $(a ̈ \tau \iota \mu \circ)$ being refused admittance, but all alike, both men and women, being allowed to come into the court, and even upon the place of speaking ... And one [respectable citizen] had the courage to say, that since the king had committed so important a cause to the judgment of the people, it would be well that the strangers and the slaves should withdraw. But the populace would not endure it, crying out they were oligarchs, and enemies of the people ( $\mu \iota \sigma o ́ \delta \eta \mu o \iota)$, and deserved to be stoned; after which no man durst offer anything further in Phocion's behalf. ${ }^{91}$

It is interesting here that the proposal to expel the foreigners and slaves from the assembly meeting is labelled oligarchic and anti-democratic. ${ }^{92}$

\section{IDENTITY, SPACE AND DEMOCRACY}

One final possible counter-argument must be answered. What is the point of talking about free spaces? For, surely, many Greek cities had agoras similar to Athens, and the kind of free space envisaged in this discussion must have been quite common in very many societies; Rome, for example, certainly had similar free spaces of interaction, yet the analysis envisaged here for Athens would hardly fit Rome. ${ }^{93}$ Can we explain the peculiar blurring of identities that we find in Athens by means of a form of space that would have been common to very many societies? We need therefore to locate a particular feature which is peculiar to Athens; and this, it seems to me, is the peculiar nature of Athenian democracy. Athenian democracy had a peculiar nature that modern scholars have been unwilling to accept, despite the fact that such a view

89 Against Meidias 182.

90 Against Meidias 193. See D. MacDowell, Demosthenes, Against Meidias (Oxford, 1990), ad loc.

91 Plut. Life of Phocion 34.

92 See H.-J. Gehrke, Phokion: Studien zur Erfassung seiner historischen Gestalt (Munich, 1976), 110-20. L. A. Trittle, Phocion the Good (London, 1988), 140, fails even to mention the presence of slaves and foreigners in Phocion's trial.

93 See H. Mouritsen, Plebs and Politics in the Late Roman Republic (Cambridge, 2001). 
is backed by the sound credentials of Aristotle. ${ }^{94} \mathrm{He}$ insists that there are various kinds of democracies and oligarchies, because of the varying nature of the parts of the population that support each form of constitution:

Now the reason of there being several forms of constitution is that every polis has a considerable number of parts $\left(\mu \epsilon^{\prime} \rho \eta\right) .95$

For there are several classes both of the people and of those called the notables; for instance, classes of the people are, one, the farmers $(\gamma \in \omega \rho \gamma \circ i)$, another, the class dealing with the crafts

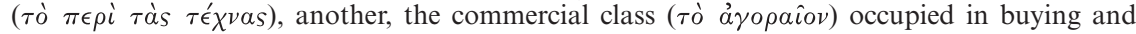
selling and another, the one occupied with the sea-and this is divided into the classes concerned with naval warfare, with trade, with ferrying passengers and with fishing (for each of these classes is extremely numerous in various places, for instance fishermen at Taras and Byzantium, crews of triremes at Athens, merchant seamen at Aegina and Chios, ferrymen at Tenedos) and in addition to these the hand-working class ( $\tau \dot{o} \chi \epsilon \rho \nu \eta \tau \iota \kappa o ́ v)$ and the people possessing little property so that they cannot live a life of leisure, also those that are not free men of citizen parentage on both sides, and any other similar class of common people. ${ }^{96}$

Aristotle tells us that different poleis are composed of different parts and some poleis can have a substantial non-agricultural population. Instead of the homogenising picture of the consumer city model, he recognizes that ancient poleis each have a different social composition, because they participate in a wider system that attaches a particular role to every polis as part of an international division of labour. ${ }^{97}$ Moreover, Aristotle not only argues that democracy and oligarchy each have a different social composition; ${ }^{98}$ he also insists that there are various forms of democracy and oligarchy, because there are various forms of working people and notables:

Now it has been stated before what kind of democracy is suited to what kind of polis, and similarly which of the kinds of oligarchy is suited to what kind of populace ... In fact there are two causes for there being several kinds of democracy, first the one stated before, the fact that the populations are different (for we find one multitude engaged in agriculture and another

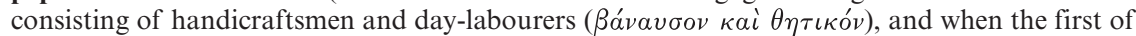
these is added to the second and again the third to both of them it not only makes a difference in that the quality of the democracy becomes better or worse but also by its becoming different in kind) .99

But quite clearly, other kinds of democracy are based on different sorts of population, where the multitude does not live by agriculture or pasturing. And Aristotle

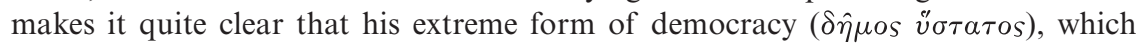
resembles Athenian democracy in a number of ways, is constituted by a population with a substantial proportion of wage labourers, artisans and traders:

Every form of democracy accords with the prevailing form of demos; if the multitude ( $\pi \lambda \hat{\eta} \theta 0 s)$ of peasants $(\gamma \in \omega \rho \gamma \circ i)$ is preponderant, then we have the first form of democracy; if the

${ }^{94}$ See A. Lintott, 'Aristotle and democracy', CQ 42 (1992), 114-28; C. Eucken, 'Der aristotelische Demokratiebegriff und sein historisches Umfeld', in G. Patzig (ed.), Aristoteles Politik: Akten des XI. Symposion Aristotelicum (Göttingen, 1990), 277-91.

${ }^{95}$ Politics $1289 \mathrm{~b} 27-35$.

${ }^{96}$ Politics 1291b17-27; see also 1290b37-1291a10.

${ }^{97}$ For an approach that recognizes the multiplicity of the composition of Greek poleis, see H.-J. Gehrke, Jenseits von Athen und Sparta. Das dritte Griechenland und seine Staatenwelt (Munich, 1986).

${ }^{98}$ Politics $1290 \mathrm{~b}$.

${ }^{99}$ Politics 1317a12-29; see also 1318b7-14. 


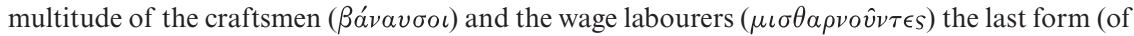
democracy) and likewise for the rest of those in between. ${ }^{100}$

In a recent study, Harris has counted 170 different professions existing in classical Athens, mostly in trade and crafts; although it is undoubtedly true that this does not reflect horizontal specialization, it still testifies to the large number of people employed in trade and manufacture. ${ }^{101}$ It is only by these means that one can explain the fact that Athens depended to an unprecedented extent in the Aegean world on the importation of cereals for its subsistence: ${ }^{102}$ since we do not have any real evidence for Athenian extensive specialization in cash crops, which would necessitate the importation of cereals, it follows that the reason behind the extensive importation was the fact that a large number of the population of Attica was not employed in the production of cereals, but in mining, crafts, transport and exchange.

When Dionysus takes as a matter of course that he will encounter on his way to Hades the bakers' shops along with the 'harbours, brothels, rest stops, detours, springs, and roads, the towns, their customs, and the inns, where there are fewest bugs', ${ }^{103}$ this shows how widespread bakeries were and the large numbers of people that depended on them to buy their foodstuffs, instead of growing them themselves. ${ }^{104}$ Nicias provides eloquent testimony to the large numbers of bakers and mills, while speaking about Athenian preparations for the Sicilian expedition:

We must take our own corn in merchant vessels, that is to say, wheat and parched barley, and bakers from the mills compelled to serve for pay in the proper proportion; in order that in case of our being weather-bound the armament may not want provisions, as it is not every city that will be able to entertain numbers like ours. 105

The Athenian fascination with fish, and the importance of fish in Athenian diet, is precisely the indication of a large urban population, which is not directly involved in agriculture; the cheap fish of the Knights caters for precisely this audience. ${ }^{106}$

All this evidence shows that a large, though indeterminate, proportion of the Athenian population was involved in buying and selling, rowing, the crafts, and wage labour. To argue that the majority of the population was still involved in agriculture is both correct and misleading: it was not before the twentieth century that in industrial countries the majority of the population was not involved in agriculture; what matters is the proportion of non-agricultural population in relationship to other preindustrial societies, and in this respect all the evidence shows that Athens qualified for Aristotle's formulation of the extreme form of democracy. ${ }^{107}$

100 Politics $1296 \mathrm{~b} 27-31$.

101 Harris (n. 8) gives an estimate of 10,000 citizens (one-third of the citizen population) involved in trade and manufacture.

102 M. Whitby, 'The grain trade of Athens in the fourth century B.C.', in H. Parkins and C. Smith (edd.), Trade, Traders and the Ancient City (London-New York, 1998), 102-28.

103 Aristophanes, Frogs 111-15.

104 On market production, see R. Osborne, 'Pride and prejudice, sense and subsistence: exchange and society in the Greek city', in J. Rich and A. Wallace-Hadrill (edd.), City and Country in the Ancient World (London, 1991), 119-145; S. Hodkinson, 'Imperialist democracy and market-oriented pastoral production in classical Athens', Anthropozoologica 16 (1992), 53-60.

105 Thucydides 6.22.

106 See e.g. Aristophanes, Knights 647-50; Davidson (n. 82), 3-35.

107 This is not an argument about ancient industrialization. The level of division of labour and of technological progress was clearly low in comparison with other pre-industrial societies; see 
It is clear that contemporaries thought that the participation of the substantial numbers of wage labourers, artisans and traders in Athenian democracy was one of its more crucial features. Athenian reactionaries, like Plato and Xenophon, particularly detested this feature. ${ }^{108}$ Xenophon's Socrates advises the noble Charmides, who did not participate in the assembly:

Are you ashamed of the fullers, or the cobblers, or the carpenters, or the smiths, or the peasants, or the traders, or those who exchange in the agora and take care how to buy cheap and sell dear? Because it is precisely from these persons that the assembly is comprised. ${ }^{109}$

The world of the Athenian demos, the poor craftsmen, shopkeepers, manual labourers, rowers, peasants and Lumpenproletariat remains still largely unexplored; ${ }^{110}$ Ehrenberg's study ${ }^{111}$ is still the only one discussing them to some extent, and despite its value, it is mainly concerned with comedy and is not characterized by its methodological or theoretical sophistication.

The inclusion of the artisan, the wage labourer and the shopkeeper into the politeia had a drastic effect on the whole of the population, including slaves, metics and women; the reason was that it destroyed any general discrimination against artisans, workers and shopkeepers as such. In other words, the inclusion of urban workers in the politeia had effects that the inclusion of small peasants did not. Since the ownership of even tiny plots was restricted to citizens, the inclusion of poor peasants had no great effect on metics and slaves. But the inclusion of urban artisans, wage labourers, and shopkeepers did have a profound effect, since there were as many metics and slaves working in urban trades, as there were citizens. ${ }^{112}$ In Thebes, when you would see an artisan, you would know that no matter whether Theban, or metic or slave, he did not participate fully in the politeia; he was a subaltern by definition. ${ }^{113}$

This was clearly not the case in Athens. Pancleon the fuller, the protean figure we discussed earlier, resided in both Thebes and Athens for some time; ${ }^{114}$ but if he could pass off as a citizen in Athens, no matter what his actual status, he could certainly not do so in Thebes. As the Old Oligarch well recognized, in the passage mentioned above (n. 11), the enfranchisement of the poor working citizens had an effect that extended even to slaves; the fact that it was impossible to discriminate against artisans, wage-labourers or more general poor people as such, because some of them were citizens with important rights and power, meant that this protection and freedom would extend, to some extent, even to slaves and metics who exercised similar pro-

M. I. Finley, 'Technical innovation and economic progress in the ancient world', reprinted in Finley (n. 50), 176-95. But this does not negate the fact that a large and significant proportion of the population did not depend on agriculture to make a living.

108 T. Morawetz, Der Demos als Tyrann und Banause: Aspekte antidemokratischer Polemik im Athen des 5. und 4. Jahrhundert (Frankfurt-New York, 2000).

109 Memorabilia 3.7.6.

110 Leading to unsatisfactory and misleading generalizations (the mass), like those adopted by Ober (n. 17), 11: 'The term "masses" can be used to refer to all members of society who are not members of an elite.' On craftsmen, see L. Neesen, Demiourgoi und artifices. Studien zur Stellung freier Handwerker in antiken Städten (Frankfurt am Main, 1989).

111 Ehrenberg (n. 17).

112 See e.g. R. H. Randall, 'The Erechteum workmen', AJA 57 (1953), 199-210.

113 Aristotle tells us that in Thebes abstaining from the agora for ten years was a precondition of magistracy, Politics 1278a25. In general, see M. Ostwald, Oligarchia: The Development of a Constitutional Form in Ancient Greece (Stuttgart, 2000).

114 Lysias, 23.15. 
fessions. In fact, as Aristotle well recognized, this protection and freedom extended even to women:

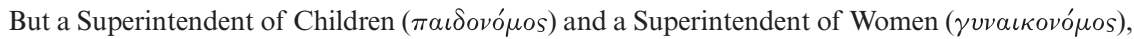
and any other magistrates that exercise a similar sort of supervision, are an aristocratic feature, and not democratic (for how is it possible to prevent the wives of the poor from going out of doors?) nor yet oligarchic (for the wives of oligarchic rulers are luxurious). ${ }^{115}$

The women of the poor had to work along with their husbands, and given that their husbands had political power and had to be treated with respect, this would be extended to a certain extent to women too. To recapitulate: my central tenet is that the inclusion of poor peasants, wage labourers, artisans and shopkeepers in the body politic had an important, though unintended, liberating effect on the rest of the population; this effect materialized in the free space of the agora. The blurring of identities is the visible result of this important development.

\section{CONCLUSION}

I have argued that the blurring of identities that we so often see in classical Athens is the effect of different dimensions of space. Athens was a very large polis and she had a peculiar system of hereditary citizenship, which facilitated the blurring of identities; Athens was also a cosmopolitan centre, where large numbers of foreigners resided, and acculturation made easy distinctions difficult; but fundamentally, it is the interaction of citizens, slaves, metics and women in the free spaces created by the peculiar nature of Athenian democracy, which can explain to an important extent the phenomenon at hand.

If the above argument is right, then we are in urgent need of alternative models of analysing social life and political action in the ancient world. ${ }^{116}$ Pauline SchmittPantel has analysed very elaborately the importance in democratic Athens of

the specialisation of certain pre-existent collective practices in the expression of political power. The choice of these practices may result from the fact that they simplified the task of putting this attempt at egalitarian abstraction into concrete form, because they were less directly dependent on a social order which was still inegalitarian ... Thereafter only certain collective activities - the assemblies, the lawcourts, the magistracies - express common sovereignty and the access to arche, political power, at Athens. ${ }^{117}$

As she goes on to argue, there remained other forms of collective activities, like cult associations and the banquet, which, although outside the newly constructed field of the political, were particularly important for the formation of political and social identities, because they were occasions of shared experience. Unfortunately, she follows the writing off of other collective activities by the new field of the political by excluding from her larger field of collective activities those without political rights: women, metics, slaves. My argument tries to move one step further, by reinserting in our mental topographies these invisible, yet always present, people and by tracing the implications following from this. In particular, I have stressed the role of shared space

115 Politics 1300a4-9.

116 For a similar plea, see M. Katz, 'Women and democracy in ancient Greece', in T. M. Falkner, N. Felson and D. Konstan (edd.), Contextualising Classics: Ideology, Performance, Dialogue. Essays in Honor of John J. Peradotto (Lanham, 1999), 41-68.

117 P. Schmitt-Pantel, 'Collective activities and the political in the Greek city', in O. Murray and S. Price (edd.), The Greek City-state from Homer to Alexander (Oxford, 1990), 203. 
in forming the shared experiences I have explored. There are other shared free spaces which remain to be explored in the future: the workshop, the tavern, the ship, the neighbourhood, and the cemetery. Can we create a new paradigm for studying Athenian democracy based on this perspective? This remains to be seen.

University of Nottingham

KOSTAS VLASSOPOULOS konstantinos.vlassopoulos@nottingham.ac.uk 